\title{
PENDETEKSIAN POSISI PLAT NOMOR MOBIL MENGGUNAKAN METODE MORFOLOGI DENGAN OPERASI DILASI, FILLING HOLES, DAN OPENING
}

\author{
Arini $^{1}$, Feri Fahrianto ${ }^{2}$, Andre Agusta $^{3}$, Asep Taufik Muharam \\ 1,2,3,4 Teknik Informatika, Fakultas Sains dan Teknologi \\ Universitas Islam Negeri Syarif Hidayatullah Jakarta \\ Jl. Ir. H. Juanda No. 95, Ciputat 15412 Telp. (62-21) 7493606 \\ 3andreagusta00@gmail.com
}

\begin{abstract}
ABSTRAK
Automatic License Plate Recognition (ALPR) telah menjadi suatu aplikasi yang sangat penting dalam beberapa tahun terakhir. Sistem pengenalan plat nomor pada umumnya memerlukan beberapa tahapan proses yaitu pengambilan citra, pendeteksian posisi plat, segmentasi karakter pada plat, dan pengenalan karakter tersebut. Pada penelitian ini, sistem yang dibuat hanya melakukan hingga pada proses pendeteksian posisi plat, yaitu tahap mendeteksi letak dan melakukan pemotongan citra obyek plat nomor mobil yang dapat dijadikan dasar untuk pengembangan lebih jauh. Pada penelitian ini penulis menerapkan salah satu metode, yakni metode morfologi dalam pendeteksian posisi plat nomor mobil dalam suatu citra. Operasi-operasi morfologi yang digunakan yaitu operasi dilasi, opening, dan filling holes, untuk mendeteksi posisi dari plat nomor mobil dalam sebuah citra. Hasil dari penelitian ini, didapatkan bahwa metode morfologi dengan operasi Dilasi, Filling Holes, dan Opening dapat diterapkan dalam proses pendeteksian posisi plat nomor mobil. Dari 25 citra sampel yang digunakan, 20 citra plat dapat terdeteksi. Sedangkan 5 citra plat tidak dapat terdeteksi.
\end{abstract}

Kata Kunci: ALPR, Pendeteksian Posisi Plat, Dilasi, Filling Holes, Opening

\subsection{Latar Belakang}

\section{Pendahuluan}

Sistem pengenal/pengidentifikasi mobil otomatis atau Automatic License Plate Recognition (ALPR) telah menjadi suatu aplikasi yang sangat penting dalam beberapa tahun terakhir. ALPR dapat digunakan dalam berbagai jenis aplikasi seperti koleksi data plat mobil yang melewati jalan tol, traffic surveillance, sistem keamanan parkir, dan sistem lainnya yang membutuhkan pengenalan plat. Sistem pengenalan plat pada umumnya memerlukan beberapa tahapan proses yaitu pengambilan citra, pendeteksian posisi plat, segmentasi karakter pada plat, dan pengenalan karakter tersebut [1].

Dalam jurnal yang berjudul, Survey on Automatic Vehicle Number PlateLocalization dijelaskan bahwa terdapat berbagai macam metode yang dapat diterapkan dalam pendeteksian posisi pada plat nomor mobil seperti metode edge information, connected component analysis, color information, texture features,sliding concentric windows, analisis wavelet, dan morfologi citra. Pada penelitian lain yang berjudul, Pengenalan Plat Nomor Mobil Secara Otomatis Untuk Pelanggaran Lalu Lintas dilakukan proses pendeteksian posisi plat nomor dengan menggunakan metode deteksi tepi (edge information). Dalam penelitian tersebut, dari pengujian terhadap 25 citra dihasilkan plat nomor yang berhasil terdeteksi memiliki tingkat keakuratan sebesar $72 \%$. Pada penelitian yang berjudul, Indian Vehicle License Plate Extraction and Segmentation dilakukan proses deteksi posisi plat nomor dengan menggunakan metode morfologi dengan operasi Opening dan Closing. Dan plat nomor yang berhasil terdeteksi memiliki tingkat keakuratan sebesar 91,02\%. Berdasarkan uraian diatas dalam penelitian ini penulis menyimpulkan bahwa tingkat keakuratan metode morfologi lebih baik untuk diterapkan dalam pendeteksian posisi plat nomor mobil dalam suatu citra. Operasi morfologi yang akan digunakan yaitu proses dilasi, opening, dan filling holes, untuk mendeteksi posisi dari plat nomor mobil dalam sebuah citra.

\subsection{Rumusan Masalah}

Bagaimana mendeteksi posisi plat nomor mobil dengan menggunakan metode morfologi?

\subsection{Batasan Masalah}

1. Penelitian ini hanya melakukan deteksi letak plat nomor dan melakukan pemotongan citra mobil.

2. Penelitian ini menggunakan operasi morfologi dan deteksi tepi.

3. Citra yang digunakan merupakan citra plat nomor kendaraan bermotor perseorangan (plat berwarna hitam) yang digunakan di Indonesia. 
4. Citra masukan diambil menggunakan kamera digital dan kamera smartphone.

5. Citra yang digunakan diambil dengan sudut pandang dari depan, tegak lurus dan ketentuan jarak $\pm 100 \mathrm{~cm}-150 \mathrm{~cm}$.

6. Waktu pengambilan sampel citra pada pukul $14.00-16.00$ WIB.

7. Citra yang digunakan sebagai bahan penelitian sebanyak 25 sampel dengan format .jpeg.

8. Perangkat lunak yang digunakan dalam penelitian ini adalah Matlab R2013a.

\section{TINJAUAN PUSTAKA}

\subsection{Citra Digital}

Menurut Fahmi [2], pemrosesan citra dengan menggunakan komputer membutuhkan citra digital sebagai masukannya. Citra digital merupakan gambar dua dimensi yang dapat ditampilkan pada layar monitor computer sebagai himpunan berhingga (diskrit) nilai digital yang disebut dengan pixel (picture elements). Citra digital adalah citra kontinu yang diubah dalam bentuk diskrit, baik koordinat ruang maupun intensitas cahayanya.

Citra digital dapat dinyatakan dalam bentuk matriks dua dimensi $f(x, y)$ dimana ' $\mathrm{x}$ ' dan ' $\mathrm{y}$ ' merupakan koordinat pixel dan 'f' merupakan derajat intensitas pixel tersebut, hal tersebut diilustrasikan pada gambar dibawah ini.

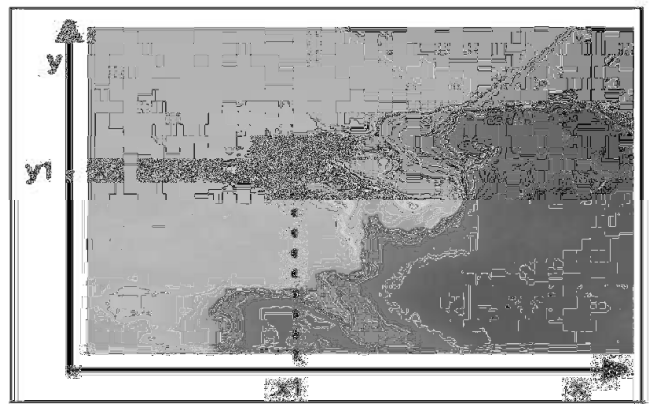

Gambar 1.Citra digital dalam bentuk matriks dua dimensi

\subsection{Morfologi}

Morfologi adalah alat untuk mengekstrak komponen-komponen citra yang berguna dalam representasi dan deskripsi dari suatu bentuk wilayah dalam citra. [3]

Pada operasi morfologi, nilai dari tiap piksel pada citra keluaran didasarkan pada perbandingan dari piksel pada citra masukkan dengan piksel di sekitarnya. Dengan menentukan ukuran dan bentuk dari neighborhood, kita dapat membangun suatu operasi morfologi yang sensitif terhadap suatu bentuk spesifik di citra masukkan. Jumlah piksel yang ditambahkan atau dihilangkan tergantung dari ukuran dan bentuk dari Structuring Element yang digunakan untuk memproses citra.

\subsection{Structuring Elements}

Structuring elements (strel) adalah himpunan kecil atau sub-image yang digunakan untuk meneliti citra dalam pembelajaran propertinya. Structuring elements dua dimensi memiliki ukuran yang biasanya jauh lebih kecil dibanding dengan citra yang diolah. Piksel pada bagian tengah dari structuring element biasa disebut dengan origin, origin mengidentifikasi piksel yang menjadi inti perhatian. [4]

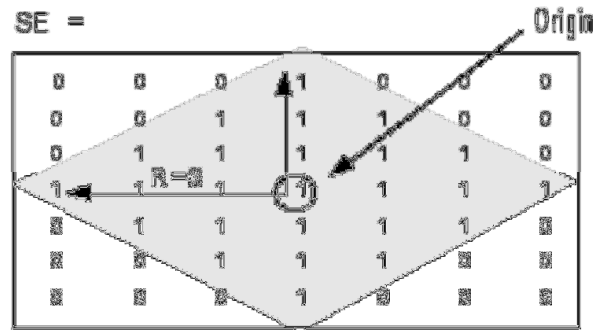

Gambar 2.Structuring Elements

Dalam morfologi, yang menjadi kunci penting adalah pemilihan strel. Strel memiliki dua komponen penting yaitu bentuk dan ukuran, keduanya sangat mempengaruhi hasil operasi morfologi. Pemilihan structuring element (strel) sangat mempengaruhi hasil pemrosesan citra. Penggunaan dua buah structuring element yang berbeda akan menghasilkan hasil yang berbeda meski obyek/citra yang dianalisa adalah sama.

Ada beberapa bentuk structuring element yang biasa digunakan, yaitu rectangle, square, disk, linear, dan diamond. Setiap bentuk structuring element tersebut memiliki kelebihan dan kekurangan masing-masing. [5]

\subsection{Dilasi}

Dilasi merupakan suatu proses menambahkan piksel pada batasan dari objek dalam suatu gambar sehingga nantinya apabila dilakukan operasi ini maka gambar hasilnya lebih besar ukurannya dibandingkan dengan gambar aslinya. Operasi dilasi dilakukan untuk memperbesar ukuran segmen objek dengan menambah lapisan di sekeliling objek. [4]

Dilasi ini sangat berguna ketika diterapkan dalam obyek-obyek yang terputus dikarenakan 
hasil pengambilan citra yang terganggu oleh noise, kerusakan obyek fisik yang dijadikan citra digital, atau disebabkan resolusi yang jelek, misalnya teks pada kertas yang sudah agak rusak sehingga bentuk hurufnya terputus, dan sebagainya. Dengan melakukan dilasi maka obyek atau tepi citra dapat disambung kembali.

\subsection{Filling Holes}

Tujuan dari Region Filling adalah mengisi keseluruhan region dengan nilai 1 [3]. Operasi ini menggunakan acuan berdasarkan nilai piksel tetangganya seperti yang ditunjukkan pada gambar di bawah ini.

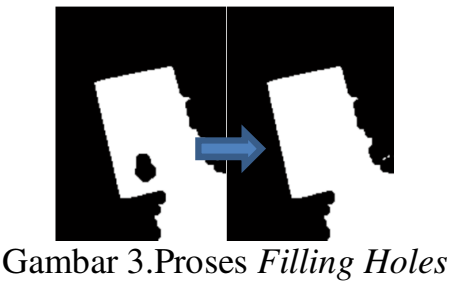

Dari Gambar diatas, dapat dilihat bahwa sebuah citra awal yang memiliki sebuah lubang (hole) dapat dihilangkan dengan operasi region filling.Citra masukan adalah citra biner yang memiliki lubang, kemudian dilakukan pengisian sehingga diperoleh segmen obyek yang pejal/solid.

\subsection{Opening}

Opening secara umum menghaluskan garisgaris bentuk obyek, menghilangkan bagianbagian sempit, dan menghilangkan penonjolanpenonjolan yang tipis [4]. Efek yang dihasilkan adalah menghilangnya obyek-obyek kecil dan kurus, memecah obyek pada titik-titik yang kurus, dan secaara umum menghaluskan batas dari obyek besar tanpa mengubah area obyek. Berikut ini merupakan contoh dari proses operasi opening:

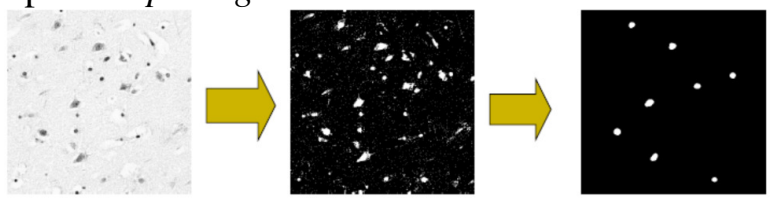

Gambar 4.Proses Opening

\section{PERANCANGAN SISTEM}

Secara umum, percobaanakan mengikuti alurimage processing sesuai dengan Gambar 5. Pada penelitian ini, parameter yang digunakan adalah plat nomor yang berhasil dideteksi atau tidak/gagal. Plat nomor yang berhasil dideteksi adalah citra keluaran yang didapat berupa citra plat nomor utuh. Sedangkan yang tidak/gagal terdeteksi adalah citra keluaran yang didapat berupa citra yang bukan merupakan plat nomor Pada penelitian ini, citra sampel yang menjadi input akan melalui beberapa tahap proses image processing yaitu, tahap resizing citra, pengambangan (Grayscaling), deteksi tepi dengan Sobel, proses morfologi citra, pemberian label, serta proses pemotongan citra untuk mendapatkan keluaran citra plat nomor.

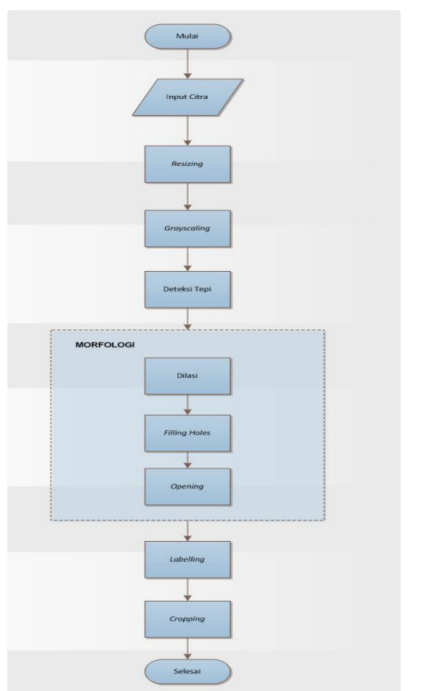

Gambar 5.Alur Image Processing

\subsection{Akuisisi Citra}

Pada tahap akuisisi citra, data yang didapatkan dari hasil pengumpulan data merupakan citra dengan berbagai ukuran, jarak, dan waktu pengambilan sampel.

\subsection{Resizing}

Proses ini bertujuan untuk mempercepat proses pengolahan citra. Pada awalnya citra sampel memiliki ukuran pixel yang besar, apabila ukuran asli citra sampel tetap dipertahankan, maka akan memperlambat proses pendeteksian.

\subsection{Grayscaling (Konversi Citra)}

Pada proses ini, citra hasil resizing selanjutnya diolah dengan mengkonversi citra menjadi citra berskala keabuan (grayscale). Karena citra hasil resizing merupakan citra dengan model warna RGB. Model warna yang terlalu kompleks, karena menggunakan tiga layer warna, yaitu Red, Green, dan Blue. 


\subsection{Segmentasi}

Pada proses segmentasi, citra hasil grayscaling selanjutnya diolah dengan menggunakan deteksi tepi. Dimana pada proses ini, citra hasil grayscale dilakukan proses pendeteksian tepi yang bertujuan untuk meningkatkan penampakan garis batas atau daerah pada suatu citra.

\subsection{Dilasi}

Pada proses ini, citra hasil deteksi tepi diolah dengan menggunakan metode morfologi. Metode morfologi digunakan untuk menghilangkan bagian dari citra yang tidak dibutuhkan. Pada tahap ini proses morfologi yaitu dilasi. Proses dilasi dilakukan untuk penumbuhan atau penebalan pada objek citra.

\subsection{Filling Holes}

Pada tahapan ini, dilakukan rekonstruksi citra kembali dengan menggunakan fungsi imfill pada Matlab. Fungsi imfill digunakan untuk menutupi lubang - lubang pada citra.

\subsection{Opening}

Pada proses opening ini, bagian - bagian sempit, penonjolan - penonjolan bagian yang tipis dihilangkan, dan menghaluskan garis-garis bentuk obyek.

\subsection{Labelling}

Pada tahap ini, citra hasil proses opening akan diproses untuk mendapatkan nilai matriks dari citra atau dapat juga diartikan labelling adalah tahapan dimana suatu area akan ditandai sebagai objek yang dikenali untuk mempermudah pendeteksian lokasi.

\subsection{Cropping}

Pada tahap ini, posisi citra yang telah ditandai/ dikenali pada proses sebelumnya akan melalui proses pemotongan citra.

\section{HASIL DAN PEMBAHASAN}

\subsection{Akuisisi Citra}

Dari pengambilan citra asli terhadap 25 kendaraan mobil, secara otomatis didapat juga 25 citra plat nomor yang unik. Berikut adalah tabel spesifikasi citra sampel.
Tabel 4.1.Spesifikasi Citra Sampel

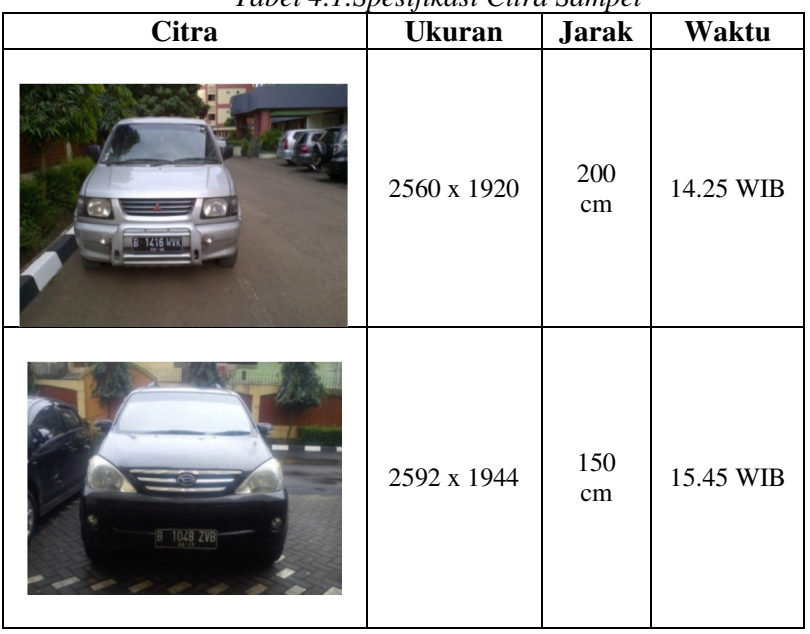

Dari pengambilan sampel tersebut dapat diketahui bahwa gambar yang diambil dengan jarak 1,5 - 2 meter, pada rentang waktu 14.00 - 16.00 dan posisi kamera di depan kendaraan, menangkap gambar plat nomor cukup baik. Karena posisi plat nomor terlihat jelas dan cukup baik, dan juga tidak ada cahaya yang memantul, sehingga akan mempermudah pendeteksian posisi plat nomor pada proses selanjutnya.

\subsection{Resizing}

Hasil pada tahapan resizing ini merupakan output dari citra sampel yang telah mengalami perubahan ukuran citra. Ukuran citra yang digunakan adalah $480 \times$ NaN. Berikut kode program pada Matlab:

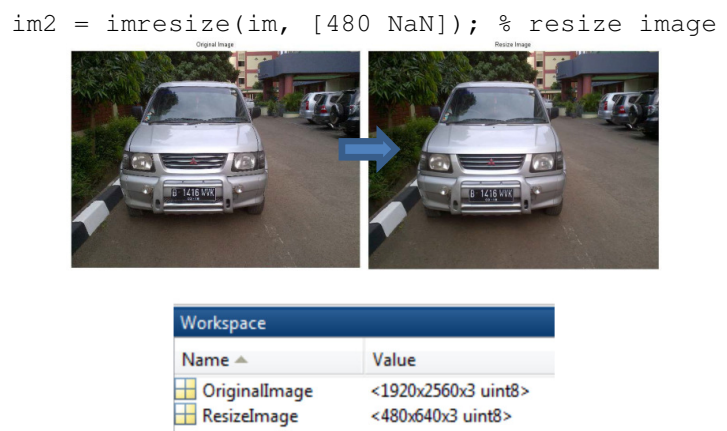

Gambar 6. Perubahan Ukuran

\subsection{Grayscaling (Konversi Citra)}

Proses converting warna, dari warna RGB menjadi Grayscale, pada Matlab digunakan fungsi rgb2gray untuk menghasilkan citra keluaran yang memiliki warna keabuan. Kode program pada Matlab:

$$
\begin{aligned}
& \text { im2 }=\text { rgb2gray }(\mathrm{im}) ; \% \\
& \text { mengkonversi image menjadi } \\
& \text { grayscale }
\end{aligned}
$$



berikut:

Hasil dari proses tersebut adalah sebagai

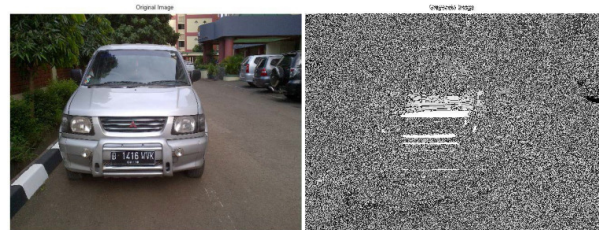

Gambar 7. Konversi citra dari RGB menjadi Grayscale

\subsection{Segmentasi}

Proses deteksi tepi yang digunakan pada deteksi posisi plat nomor ini yaitu metode Sobel Edge Detection. Digunakannya Sobel Edge Detection, karena metode ini dapat menghilangkan atau mengurangi noise pada citra. Kode program pada Matlab:

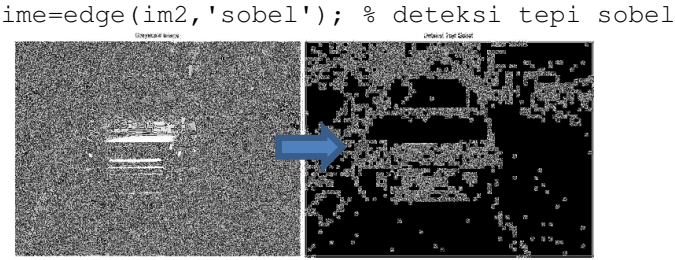

\subsection{Dilasi}

Gambar 8. Hasil Deteksi Tepi Sobel

Dilasi ini menggunakan strel bentuk disk. Karena bentuk strel disk umum digunakan dalam aplikasi pendeteksian. Selain itu, strel disk merupakan bentuk yang paling umum digunakan dalam proses morfologi. Efek yang dihasilkan merata pada segala arah, sehingga akan mempermudah untuk melakukan proses selanjutnya. Kode program pada Matlab:

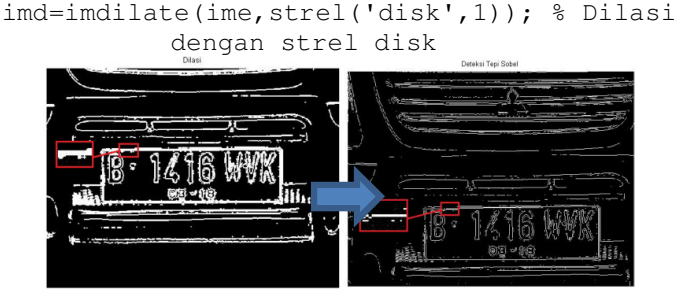

Gambar 9. Hasil Proses Dilasi

Pada gambar diatas, diketahui bahwa pada proses dilasi dengan menggunakan strel disk dengan radius 1, bagian-bagian yang pada proses sebelumnya yang hilang atau tidak jelas, kembali diperbaiki dengan menumbuhkan dan menebalkan bagian-bagian pada citra yang diperlukan untuk proses selanjutnya, agar lebih mudah dalam mendeteksi posisi plat nomor.

\subsection{Filling Holes}

Dengan menggunakan fungsi imfill untuk menutupi lubang - lubang pada citra. Lubang pada citra ini muncul, dikarenakan adanya perbedaan nilai
- nilai intensitas pada daerah tertentu. Jadi, fungsi imfill ini membawa nilai - nilai intensitas pada daerah gelap yang dikelilingi oleh area terang ke tingkat intensitas daerah yang sama dengan piksel sekitarnya. Kode program pada Matlab:

L=imfill (imd,'holes'); Fill bagian/region yang kosong

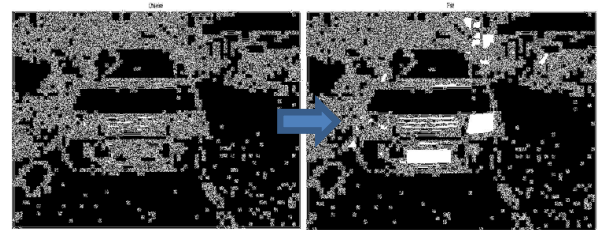

Gambar 10. Hasil Filling Holes

\subsection{Opening}

Selanjutnya, citra hasil imfill diolah dengan menggunakan proses opening. Penghilangan bagian - bagian yang diolah dengan proses opening secara horizontal dan vertikal untuk mendapatkan citra yang lebih mudah untuk di proses pada tahap Labelling/verifikasi. Kode program pada Matlab:

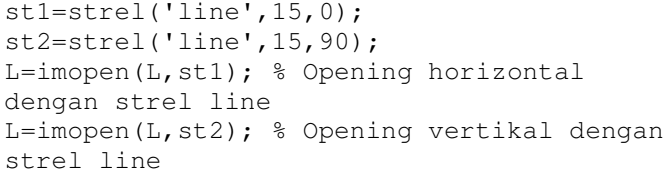

Berikut ini adalah citra hasil proses opening horizontal dan vertikal:
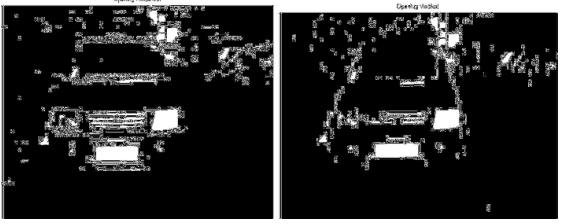

\section{Gambar 11. Citra hasil Horizontal dan Vertikal}

\subsection{Labelling}

Pada tahap ini akan dilakukan proses pelabelan dengan menggunakan fungsi BWLABEL pada aplikasi MATLAB. Citra yang telah dikonversi menjadi nilai matriks akan melalui proses untuk mendapatkan lokasi area. Jika terdapat nilai 1 terbanyak pada suatu area atau dapat dikatakan area dengan warna putih terbanyak atau terluas, maka akan ditandai dengan menggunakan regional deskriptor bounding box dan area dalam fungsi regionprops. Bounding box digunakan untuk memberi tanda kotak pada area yang mempunyai nilai putih terbanyak. Area digunakan untuk mendeskripsikan jumlah pixel yang telah ditandai oleh bounding box sebelumnya, sehingga akan didapatkan citra akhir berupa lokasi dari plat nomor 
kendaraan dari gambar input. Kode program pada Matlab:
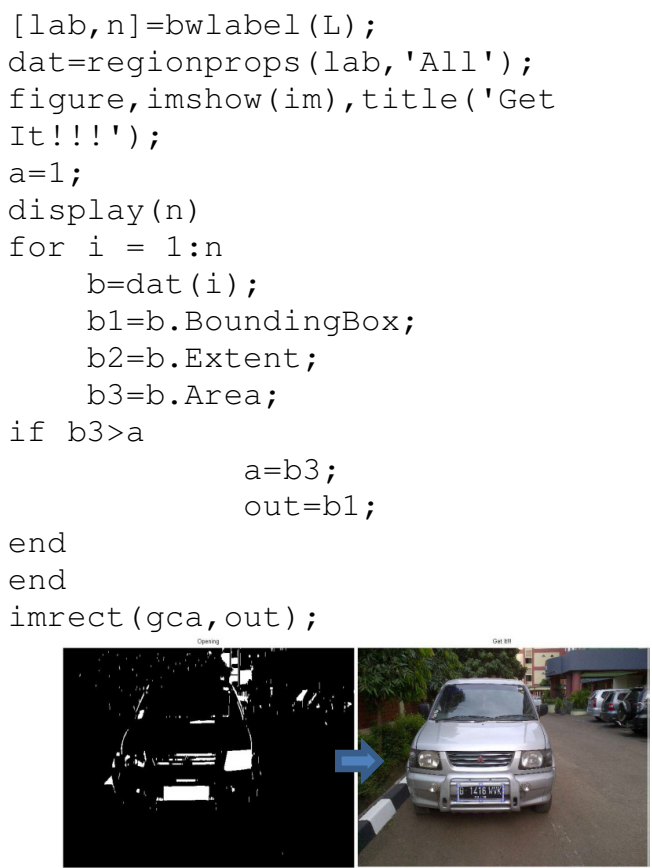

Gambar 12. Citra hasil proses Labelling

\subsection{Cropping}

Pemotongan citra yang dilakukan dengan menggunakan fungsi imcrop. Kode program pada Matlab:

im3 =imcrop (im, out) ;

figure, imshow(im3), title ('Crop') ;

Berikut ini adalah hasil dari proses Cropping dan juga merupakan citra hasil akhir/output
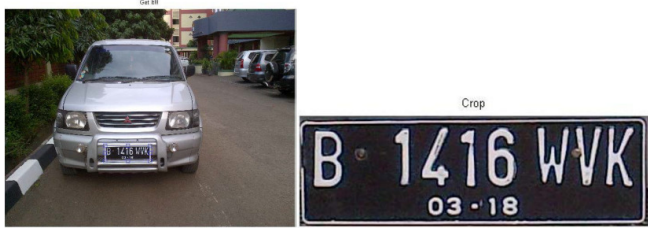

Gambar 13. Citra hasil Cropping

\subsection{Analisis Hasil Percobaaan}

\begin{tabular}{|c|c|}
\hline \multicolumn{2}{|c|}{ Tabel 2. Hasil Percobaan } \\
\hline Berhasil & Tidak berhasil/Gagal \\
\hline 20 & 5 \\
\hline
\end{tabular}

Pada citra yang telah ditampilkan pada tabel di atas, penulis dapat menyimpulkan bahwa teori pada jurnal sebelumnya dapat dibuktikan. Dimana dari 25 citra kendaraan yang penulis gunakan, 20 citra tersebut dapat mengenali dan menandai plat nomor dengan tepat. Sedangkan 5 citra mengalami kendala atau tidak dapat mengenali plat nomor. Hal ini terjadi, dikarenakan oleh beberapa sebab seperti kurangnya cahaya, pantulan cahaya, intensitas cahaya yang berlebih, dan banyaknya warna putih lain seperti pada mobil berwarna putih ataupun garis plat nomor yang terputus.

Jadi, persentase tingkat keberhasilan dari aplikasi pada penelitian ini adalah $80 \%$. Sehingga, dapat dikatakan bahwa teknik morfologi dengan operasi dilasi, filling holes, dan opening dapat digunakan untuk mendeteksi posisi plat nomor kendaraan.

\subsection{Kesimpulan}

\section{PENUTUP}

Penulis menggunakan 25 citra sampel mobil dengan metode morfologi yang diimplementasikan dalam aplikasi Matlab. Metode morfologi yang penulis implementasikan adalah proses dilasi, opening, dan filling holes. Dari 25 percobaan tersebut, 20 plat nomor dapat terdeteksi. Jadi, dapat dikatakan bahwa persentase tingkat keberhasilan dengan menggunakan metode morfologi pada penelitian ini adalah $80 \%$.

\subsection{Saran}

Aplikasi yang dibangun tentu saja masih belum sempurna. Oleh karena itu, penulis juga mengemukakan beberapa saran yang dapat berguna untuk penelitian di masa datang, yaitu :

1. Diharapkan pada penelitian selanjutnya dapat menambahkan teknik morfologi lain terkait deteksi posisi plat nomor kendaraan agar tingkat keakuratannya lebih tinggi.

2. Pada penelitian selanjutnya, diharapkan aplikasi pendeteksian lokasi plat nomor dapat berjalan dengan kondisi pencahayaan bagaimanapun, dan dengan warna mobil apapun.

3. Diharapkan pada penelitian selanjutnya, aplikasi pendeteksian lokasi plat nomor dapat mendeteksi dengan tepat, meskipun dengan jarak berapapun.

\section{DAFTAR PUSTAKA}

[1] Arnia, F, dkk., "Metode Band Limited Phase Only Correlation (BLPOC) untuk Identifikasi Plat Kendaraan", Jurnal Rekayasa Elektrika Vol. 10, No. 1, April 2012.

[2] Fahmi, Perancangan Algoritma Pengolahan Citra Mata Iris Sebagai Bentuk Antara Sistem Biometrik. Departemen Teknik Elektro, Medan, 2007

[3] Sutoyo, T, dkk., Teori Pengolahan Citra Digital. Yogyakarta: Andi, 2009.

[4] Prasetyo, Eko,Pengolahan Citra Digital dan Aplikasinya Menggunakan Matlab (ed. 1). Yogyakarta : Andi, 2011.

[5] Gang Li, dkk, "Gray-scale Edge Detection forGastric Tumor Pathologic Cell Images by Morphological Analysis", Biology andMedicine Journal, Nomor. 39, hal. 947 -952. 2009. 